\title{
Evaluación de Microorganismos de Algunos Suelos Procedentes de la Región de Azuero
}

\author{
Alexis De La Cruz L. ${ }^{1,2 *}$ \\ ${ }^{1}$ Docente e investigador de la Escuela de Biología, Facultad de Ciencias Naturales, Exactas \\ y Tecnología, Centro Regional Universitario de Azuero, Universidad de Panamá. \\ ${ }^{2}$ Profesor-Investigador, Centro de Estudios e Investigaciones en Ciencias Agrarias \\ y Ambientales, Centro Regional de la USMA en Azuero, Chitré, Panamá. \\ *Autor para correspondencia. Email: alexisdelac@gmail.com
}

Recibido: 10 de enero de 2018

Aceptado: 03 de abril de 2018

\begin{abstract}
Resumen
La cuenta viable de microorganismos del suelo puede realizarse por la técnica de cuenta en placa o la técnica del número más probable (NMP). Los principios fundamentales de estas técnicas son dispersión de una muestra en un diluyente apropiado, distribución en un medio apropiado de crecimiento, incubación bajo condiciones óptimas, y conteo de las colonias desarrolladas. La producción microbiológica de $\mathrm{CO} 2$ en el suelo puede ser determinada incubando el suelo en jarras, el objetivo de este proyecto consistió en Caracterizar los microorganismos existentes de tres tipos de suelos: Agrícola, Ganadero y Forestal, a través de múltiples técnicas de microbiología. Se seleccionará un área preferiblemente rectangular de aproximadamente 10x5 metros, sobre la cual se empleara un muestreo en forma zigzag en donde se tomaran 5 submuestras de aproximadamente $10 \mathrm{~g}$ de cada una (que se depositan en bolsas plásticas de $1 \mathrm{lb}$ ), a $20 \mathrm{~cm}$ de profundidad, para luego homogenizarla en una sola muestra. Una vez realizada el procedimiento las muestras son llevadas a la Unidad de investigación del Centro Regional Universitario de Azuero. Al finalizar este proyecto de investigación hemos llegado a la conclusión de que la Hipótesis de investigación fue aceptada ya que se presenta una mayor ocurrencia y diversidad de microorganismos en uno de los tres suelos evaluados.
\end{abstract}

Palabras Clave: Suelo, Microorganismos, Zigzag, homogenización y diversidad.

\begin{abstract}
The viable count of microorganisms in the soil may be performed by plate count technique or most probable number technique (MPN). The fundamental principles of these techniques are dispersing a sample in an appropriate diluent, distribution in an appropriate growth medium, incubation under optimal conditions, and counting the colonies developed. Microbial production of CO2 in the soil can be determined by incubating the floor akimbo, the aim of this project was to characterize the
\end{abstract}


Invest. pens. crit. (ISSN 1812-3864)

Vol. 6, No. 1, enero-abril 2018

pp. $51-64$

microorganisms of three types of soil: Agricultural, Livestock and Forestry, through multiple techniques of microbiology. one preferably rectangular area of about 10x5 meters, on which sampling is employed as zigzag where five subsamples of about $10 \mathrm{~g}$ of each (which are deposited in plastic bags $1 \mathrm{lb}$ ) were taken are selected, a $20 \mathrm{~cm}$ deep and then homogenize in a single sample. Once the procedure samples are taken to the Research Unit of the University Regional Center Azuero. Upon completion of this research project we have concluded that the research hypothesis was accepted as an increased occurrence and diversity of microorganisms in one of the three soils tested is presented Keywords: Soil, Microorganism, Zigzag, Homogenize and Diversit.

\section{Antecedentes y Justificación}

El análisis de suelo, es una importante herramienta que bien usada sirve para el diagnóstico de suelo, para determinar las propiedades edáficas así como su estado de fertilidad, lo que permitirá recomendar sobre la fertilización y verificar avances en la degradación de los suelo. (Villareal y Name, 1996). Los ambientes terrestres son heterogéneos y discontinuos, ya que contienen una gran cantidad de microorganismos. Las comunidades microbianas varían en cuanto a la profundidad y tipo de suelo, en el horizonte superficial se tiene muchos microorganismos que en otros horizontes, también las comunidades pueden variar de un sitio a otro, debido a que coexisten grandes comunidades microbianas de suelo, de allí que sea necesario tomar más de una muestra para obtener un análisis microbiano. La respiración del suelo se define como la producción total de CO2, por unidad de área y de tiempo, y se debe a la respiración de organismos edáficos, raíces, hifas micorrícicas, y en menor extensión, a la oxidación bioquímica de los compuestos de carbono (Lloyd y Taylor, 1994). La respiración del suelo constituye un evento central de los cambios ecológicos globales debido a su papel controversial en los procesos de calentamiento global ya que puede determinar si un ecosistema dado se comporta como fuente o sumidero de CO2 (Jassal et al., 2007).La catalasa forma parte de los sistemas de des-toxificación de las células animales y vegetales, y de bacterias aerobias y anaerobias facultativas. La reacción específica que cataliza es la ruptura del H2O2 para formar agua y oxígeno. El $\mathrm{H} 2 \mathrm{O} 2$ se forma en el transporte de electrones de la cadena respiratoria y en ciertas reacciones de hidroxilación y oxigenación (Alef y Nannipieri, 1998). La catalasa se relaciona con la actividad microbiana del suelo por ser una enzima intracelular presente en microorganismos aerobios y en la mayoría de los anaerobios facultativos. Durante los procesos biológicos (metabolismo) se generan especies químicas conocidas como radicales libres, los cuales se caracterizan por presentar un electrón desapareado y por ser muy reactivas. Entre estos radicales, las especies reactivas derivadas del oxígeno (EROS) resultan de gran interés debido a su estructura birradical y al gran número de procesos que las generan y en los que pueden verse involucradas. Se han empleado muchos métodos para determinar la actividad de la catalasa, los cuales miden la cantidad de oxígeno liberado (O2) o el H2O2 remanente. El oxígeno puede cuantificarse por volumetría de gases o cromatografía de gases. El H2O2 se determina por volumetría o colorimetría (García et al., 2003).Castro y Flores (2014), realizaron estudios con el objetivo de determinar la actividad, densidad microbiana y físico-química de tres suelos, con distintos sistemas de manejo agrícola, durante los meses de abril y mayo en el Ejido, corregimiento de Santa Ana, provincia de los Santos, el cual aislaron Echerichia coli, mediante la técnica de cultivo de enriquecimiento y selección por medios específicos. Los resultados encontrados en esta investigación, no arrojan diferencias significativas $(\mathrm{p}>0,05)$, respecto a la densidad microbiana en los distintos manejos agrícolas (alternativa orgánica, convencional y casa de vegetación). En cuanto a la 
Invest. pens. crit. (ISSN 1812-3864)

Vol. 6, No. 1, enero-abril 2018

pp. 51-64

actividad microbiana, la enzima deshidrogenasa presento significancia solamente para la alternativa orgánica con una $\mathrm{X}=1,54$, y respecto a la respiración no se presentaron diferencias entre los tratamientos agrícolas. Brito (2014), realizo un estudio con el objetivo de aportar al conocimiento del control de las enfermedades del suelo realizando la identificación molecular de bacterias en suelo agrícola tratado con el agente químico: 1-3 Dicloropropeno al 45\% y Cloropicrina al 55\%, y comparo su efecto versus un suelo sin la aplicación del mismo. Las muestras de suelo fueron recolectadas en la finca productora de flores "Latitud Cero". Para este estudio se evaluaron las poblaciones de bacterias del suelo en cultivo de Hypericum (familia de Hypericaceae), como resultado, se observó que el agente químico biosida destruyó gran parte de la biodiversidad de bacterias en el suelo estudiado y a su vez disminuyó la población total. Las bacterias identificadas por medio de técnicas moleculares en el tratamiento antes del biosida no fueron previamente descritas en las bases de datos siendo nuevos descubrimientos que un futuro deberán determinarse y clasificarse, mientras que el tratamiento después del biosida fueron: Bacillus megatherium, Bacillus cereus, Bacillus flexus, Bacillus bombysepticus y Pseudomonas flourescens. Esta investigación o estudio servirá como una caracterización de microorganismos presente en los suelos, ya que esto permitirá conocer qué tipo de suelos es más acto para la siembra de cultivos, el pastoreo de animales y el nacimiento de reservas forestales, además comparar con otros tipos de suelos las alteraciones que pueda llegar a tener y corregirlas mediante los datos obtenidos en este estudio brindará información valiosa a los agricultores, ganaderos y a los guarda bosques. Promoverá el desarrollo de una adecuada escogencia de los suelos. Comprobara si las condiciones de estos suelos es acta para el cultivo y el pastoreo. El objetivo de esta investigación fue, caracterizar los microorganismos existentes de tres tipos de suelos: Agrícola, Ganadero y Forestal, a través de múltiples técnicas de microbiología.

\section{Materiales y métodos}

\section{Diseño del estudio}

Para este trabajo se tomaron en cuenta tres suelos bajo las acciones ganadera, agrícola y bosque forestal, cada uno de ellos fue monitoreado en zigzag en donde se tomaran 5 submuestras y luego homogenizarla en una sola muestra. Para su debida caracterización y cuantificación de microorganismos de los tres suelos.

\section{Ubicación del estudio}

Las muestras de suelo fueron tomadas en tres puntos de la región de Azuero, para esta investigación. Los suelos fueron monitoreados en el IDIAP en La Villa de Los Santos para el suelo agrícola, en la finca de Santa Ana de Los Santos para el suelo ganadero y Los Cerritos de Los Pozos para el suelo de bosque forestal.

\section{Variables}

Dependiente: 3 tipos de suelos (agrícola, ganadero y bosque forestal) Independiente: Microorganismos. 
Invest. pens. crit. (ISSN 1812-3864)

Vol. 6, No. 1, enero-abril 2018

pp. $51-64$

\section{Hipótesis}

Hay mayor ocurrencia y diversidad de microorganismos en uno de los suelos evaluados.

\section{Recolección de las muestras}

Se seleccionará un área preferiblemente rectangular de aproximadamente 10x5 metros, sobre la cual se empleara un muestreo en forma zigzag en donde se tomaran 5 submuestras de aproximadamente $10 \mathrm{~g}$ de cada una (que se depositan en bolsas plásticas de $1 \mathrm{lb}$ ), a $20 \mathrm{~cm}$ de profundidad, para luego homogenizarla en una sola muestra.

Una vez realizada el procedimiento las muestras son llevadas a la Unidad de investigación del Centro Regional Universitario de Azuero.

Proceso de laboratorio: (Estos procedimientos son aplicados a los tres tipos de suelo)

\section{Técnica de dilución Seriada y Esparcido}

Se pesan $10 \mathrm{~g}$ de cada una de las muestras de suelo, que se depositan en una botella de vidrio contenida de agua destilada estéril, la cual se homogeniza con la muestra de suelo.

Homogenizada la solución se procede a aplicar la dilución seriada en 4 tubos de ensayo que contiene agua destilada, el cual se tomara $1 \mathrm{ml}$ de la solución, el proceso de dilución se da de esta forma, se parte de la dilución 0.1 de la 0.01 , de la 0.01 a la 0.001 , de la 0.01 a la 0.0001 .

Luego del proceso de dilución con una micropipeta se toma 0.1 microlitro, esto se sembraran en Agar Saburaud (AS), Agar ENDOLES (AE), Agar Cetrimide (AC) y Agar Plate Count (PC), por medio de la técnica de esparcido

Culminado el proceso de siembra se incuban a temperatura de $30^{\circ} \mathrm{C}$ los platos con AS, a $26^{\circ} \mathrm{C}$ los platos con $\mathrm{PC}$ y a $37^{\circ} \mathrm{C}$ los platos con $\mathrm{AE}$ y AC. En un periodo de 5 días en el caso de hongos y levaduras, y 24 horas en el caso de bacterias. Para la observación de resultados.

\section{Técnica de microscopia y Tinción de Gram}

Pasa el periodo previo de incubación, se realiza una cuantificación y caracterización de hongos y colonias de bacterias crecidas en cada medio, la tinción de Gram y verificación a través de la técnica de microscopia de la siguiente manera:

Tinción de Gram o diferencial en el AE, AC y PC, se realiza el frotis, con una pequeña gota de agua destilada, inoculando la cepa al portaobjeto con movimiento circular por unos minutos, secándola en el mechero.

Colocar una gota de violeta cristal por un minuto, y lavar con agua destilada.

Agregar una gota de lugol por 1 minuto, lavar con agua destilada 
Invest. pens. crit. (ISSN 1812-3864)

Vol. 6, No. 1, enero-abril 2018

pp. 51-64

Decolorar como sigue se hace con alcohol decolorante por 0 s, y lavar con agua destilada.

Por último se le agrega la sustancia de contraste que es safranina, para teñir las bacterias que pierden el cristal violeta, por 15 s o 1 minuto, se lava y se deja secar.

Observar al microscopio.

Tinción para hongos AS, se agrega una pequeña gota en el portaobjeto si las esporas son de color, de no ser así se agrega lacto fenol.

Se toma las esporas del hongo a identificar y se distribuyen en la gota de agua.

Se coloca el cubre objeto sobre el inóculo

Se observan al microscopio.

\section{Medición del $\mathrm{CO}_{2}$}

Incubación de la muestra de suelo en Erlenmeyer.

En un Erlenmeyer se depositan $10 \mathrm{ml}$ de agua destilada como nuestro control, al cual colocamos un tubo de hidróxido de sodio suspendido dentro del mismo Erlenmeyer.

En dos Erlenmeyer agregamos 10 gramos de suelo a el cual se rotulara como (Erlenmeyer(A) y Erlenmeyer (B))

En el Erlenmeyer (A) se coloca un tubo con hidróxido de sodio y en el Erlenmeyer (B) colocamos un tubo con sacarosa. Luego los Erlenmeyer con suelo y el Erlenmeyer control lo colocamos por 7 días en el horno a temperatura ambiente.

Siembra por esparcido:

Se utilizó $10 \mathrm{ml}$ del suelo para diluirlo en $90 \mathrm{ml}$ de agua destilada estéril de la cual se hicieron 3 diluciones (desde la $10^{-2}$ hasta la $10^{-4}$ ) en medio de cultivos:

Las 3 diluciones fueron sembradas en Agar ENDOLES para recuento de Coliformes totales. Incubación a $37^{\circ} \mathrm{C}$ por $24 \mathrm{~h}$.

Las diluciones $10^{-2} ; 10^{-3}$ y $10^{-4}$ fueron sembradas por medio de la técnica de esparcido en agar TSA. $37^{\circ} \mathrm{C}$ por $24 \mathrm{~h}$.

Las diluciones $10^{-2} ; 10^{-3} ; 10^{-4}$ fueron sembrada en Extracto de Malta agar para los recuentos de hongos y levaduras. Incubación a $25^{\circ} \mathrm{C}$ por 3 días.

Titulación:

7 días después de haber montado el sistema de respiración de suelo Animal, se procede a cuantificar la producción de $\mathrm{CO}_{2}$ y la medición de la actividad respiratoria.

Teniendo en cuenta la siguiente ecuación:

$$
\mathrm{Na}_{2} \mathrm{CO}_{3}+\mathrm{H}_{2} \mathrm{O}+\mathrm{OH}^{-}+\mathrm{BaCl}_{2} \rightarrow \mathrm{NaCl}+\mathrm{BaCO}_{2}+\mathrm{HCl}+\mathrm{BaCl}_{2}+\mathrm{HCO}_{3}+\mathrm{NaCO}_{3}
$$

Asi pues:

$$
\mathrm{CO}_{2}+2 \mathrm{NaOH} \rightarrow \mathrm{Na}_{2} \mathrm{CO}_{3}+\mathrm{H}_{2} \mathrm{O}
$$


Invest. pens. crit. (ISSN 1812-3864)

Vol. 6, No. 1, enero-abril 2018

pp. 51-64

Se evaluó el control con $100 \mathrm{ml}$ de $\mathrm{HCl}$; el suelo sin Sacarosa; y el suelo con sacarosa.

A las muestras se le añadió Fenoftaleína como indicador de cambio de color al ser titulado con $\mathrm{HCl}$.

Para después establecer la siguiente ecuación:

C- $\mathrm{CO}_{2}$ desprendido $=\frac{(\mathrm{B}-\mathrm{S}) \mathrm{xMx6}}{\mathrm{GxT}}$

\section{Activación de la catalasa en el suelo}

\section{Preparación de la muestra de suelo}

\section{Muestra:}

Se pesa 0,5 g del suelo húmedo en un Erlenmeyer y se añade $40 \mathrm{ml}$ de agua destilada, se tapa y se comienza agitar por 30 minutos en agitador rotatorio.

Luego de los 30 minutos se añadió $5 \mathrm{ml} \mathrm{de} \mathrm{H}_{2} \mathrm{O}_{2}$ y se comenzó agitar nuevamente durante 10 minutos exactos en agitador. Para la reacción enzimática y la estabilización del peróxido de hidrogeno remanente se adiciona $5 \mathrm{ml}$ de $\mathrm{H}_{2} \mathrm{SO}_{4} 1,5 \mathrm{M}$ y filtramos $25 \mathrm{ml}$.

\section{Control:}

Se prepara de igual manera que la muestra pero sustituyendo los $5 \mathrm{ml} \mathrm{de} \mathrm{H}_{2} \mathrm{O}_{2}$ por igual volumen de agua destilada.

De igual manera se le adiciono $5 \mathrm{ml}$ de H2SO4 1,5 M aunque no se le haya adicionado el peróxido de hidrogeno. Se filtran $25 \mathrm{ml}$.

\section{Blanco sin suelo:}

Se agregan $40 \mathrm{ml}$ de agua destilada en un Erlenmeyer.

Se vierten $5 \mathrm{ml}$ de $\mathrm{H}_{2} \mathrm{O}_{2} \mathrm{Y} 5 \mathrm{ml}$ de $\mathrm{H}_{2} \mathrm{SO}_{4} 1,5 \mathrm{M}$ obteniendo una solución de $\mathrm{H}_{2} \mathrm{O}_{2} 8,8 \mathrm{ml}$ (este volumen de líquido contiene un total de $0,44 \mathrm{~m}$ moles de $\mathrm{H}_{2} \mathrm{O}_{2}$ ). Se filtran $25 \mathrm{ml}$.

\section{Evaluación de la Catalasa}

\section{Titulación:}

Cada una de las muestras se titulan con Permanganato de Potasio $\mathrm{KMnO}_{4}$ 0,01 M, agitando continuamente la disolución mientras se está titulando.

El punto final de cada valoración es señalado por: (cada muestra se le toma el tiempo de titulación).

Muestra: Se termina su titulación por la incorporación al añadir la gota.

Control: se señala con la aparición de un color rodado permanente.

Blanco: su titulación inicia con la aparición de un color rosado y termina al cambiar a transparente.

Luego de titular todas las muestras se realizan los cálculos pertinentes para la evaluación de catalasa. 
Invest. pens. crit. (ISSN 1812-3864)

Vol. 6, No. 1, enero-abril 2018

pp. 51-64

$$
A E=\frac{[\mathrm{BG}-(\mathrm{S}-\mathrm{B}) \mathrm{xNx} 0.5 \mathrm{xVxt}]}{\mathrm{G}}
$$

\section{Resultados y Discusión}

Parte I: Caracterización de los suelos

Cuadro N¹: CRECIMIENTO DE TRES TIPOS DE SUELOS EN CINCO MEDIOS DE CULTIVO EN LA REGIÓN DE AZUERO. AÑO: MAYO Y JUNIO DE 2016.

\begin{tabular}{|c|c|c|c|}
\hline Medios de Cultivo & Suelo Agrícola & Suelo Forestal & Suelo Ganadero \\
\hline Agar ENDOLES & & & \\
\hline Agar Cetrimide & & & \\
\hline Agar Plate Count & & & \\
\hline Agar Tripticasa de Soja & & & \\
\hline Agar Extracto de Malta & & \begin{tabular}{|l|} 
Área del gráfico \\
\end{tabular} & \\
\hline
\end{tabular}

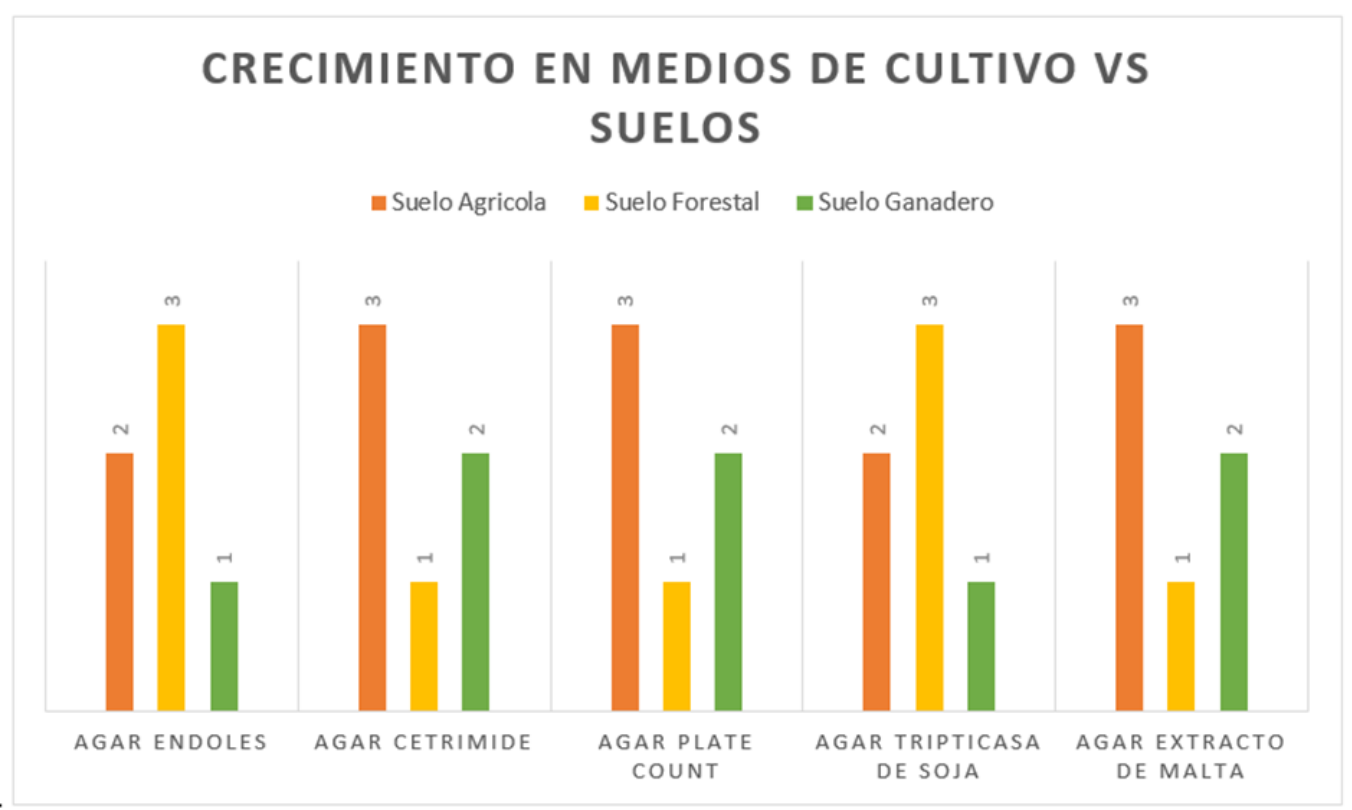

Figura N¹: Eje de las $\mathrm{Y}=$ Suelo agrícola (naranja), suelo de Bosque forestal (amarillo), suelo ganadero (verde). Eje de las $\mathrm{X}=$ Medios de cultivos (Agar ENDOLES, Agar Cetrimide, Agar plate count, Agar Tripticasa de soja, Agar Extracto de malta).

En la siguiente grafica se presenta el crecimiento de las diluciones sembradas en los cinco medios de cultivo utilizados para la elaboración de este proyecto en donde el suelo que presento un mayor crecimiento en 3 de los 5 medios de cultivo fue el suelo agrícola en los medios Agar 
Cetrimide, Agar Plate Count, Agar Extracto de Malta, seguido en agar ENDOLES y Agar Tripticasa de Soja esto se puede explicar ya que el suelo agrícola es un suelo en el cual dominan más las bacterias que los hongos en donde nuestros resultados presentaron un crecimiento equitativo entre hongos y bacterias. Seguidamente el suelo de bosque forestal presenta el mayor crecimiento en la siembra de diluciones en los medios de cultivo Agar ENDOLES y Agar Tripticasa de Soja, y crecimiento bajo en los medios Agar Cetrimide, Agar Plate Count, Agar Extracto de Malta lo que explica que en estos tipos de suelos los hongos se encuentran en mayor biomasa que las bacterias, pero en nuestro caso hubo mayor crecimiento de coliformes que de hongos debido a que el suelo fue tomado de un área cerca del río lo que puede explicar el incremento de coliformes ya que diversos factores pueden influir como el depósito de materia fecal a lo largo del río. Y por último el Suelo Ganadero presento un alto crecimiento en las diluciones sembradas en Agar Cetrimide, Agar Plate Count, Agar Extracto de Malta presentó un bajo crecimiento en los medios de Cultivo Agar ENDOLES y Agar Tripticasa de Soja, y la literatura nos dice que estos suelos el crecimiento de Bacterias coliformes es mayor que el de hongos, pero nuestros resultados arrojan un mayor crecimiento de levaduras y bajo crecimiento de bacterias coliformes.

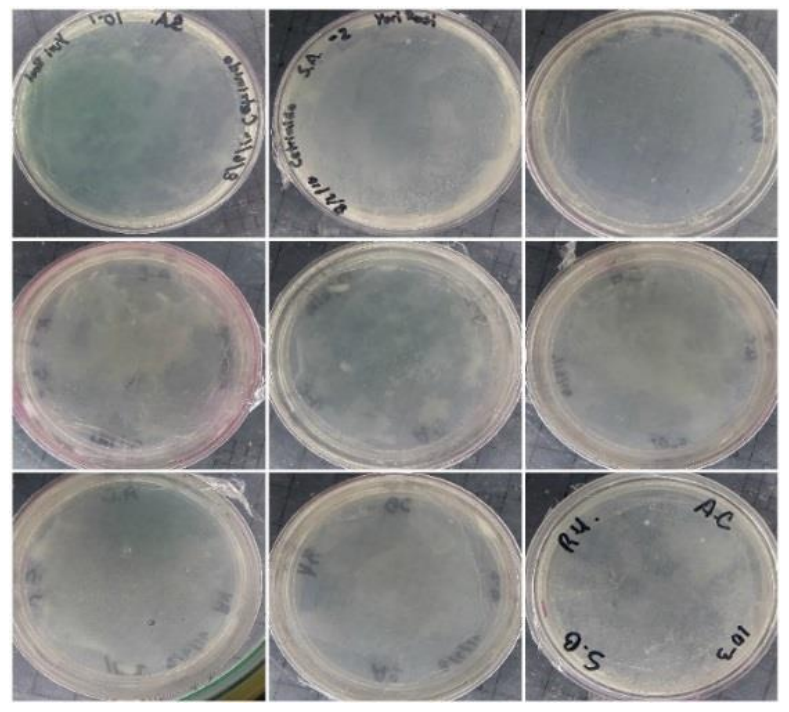

Fig.No2: Crecimiento en Agar Cetrimide y respectivas diluciones en cada suelo; A- Suelo Agrícola (A.1: Dilución 10-1, A.2: Dilución 10-2, A.3: Dilución 10-3); B- Suelo Ganadero (B.1: Dilución 10-1, B.2: Dilución 10-2, B.3: Dilución 10-3); C- Suelo Forestal (C.1: Dilución 10-1, C.2: Dilución 10-2, C.3: Dilución 10-3 
Invest. pens. crit. (ISSN 1812-3864)

Vol. 6, No. 1, enero-abril 2018

pp. 51-64

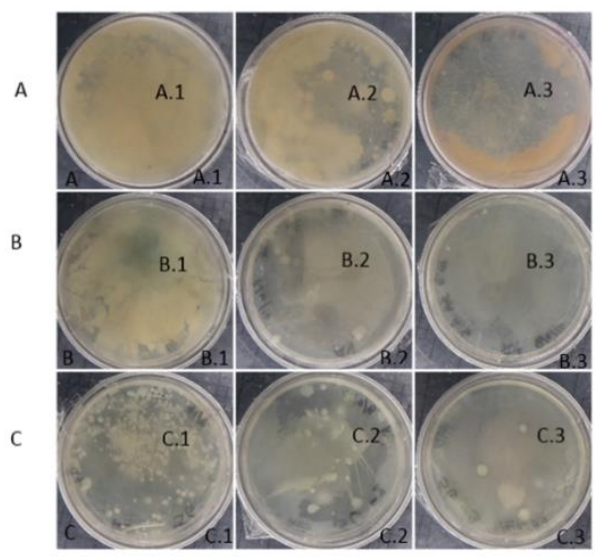

Fig. N'3: Crecimiento en Agar Tripticasa de Soja y respectivas diluciones en cada suelo; ASuelo Forestal (A.1: Dilución 10-1, A.2: Dilución 10-2, A.3: Dilución 10-3); B- Suelo Agrícola (B.1: Dilución 10-1, B.2: Dilución 10-2, B.3: Dilución 10-3); C- Suelo Ganadero (C.1: Dilución 10-1, C.2: Dilución 10-2, C.3: Dilución 10-3).

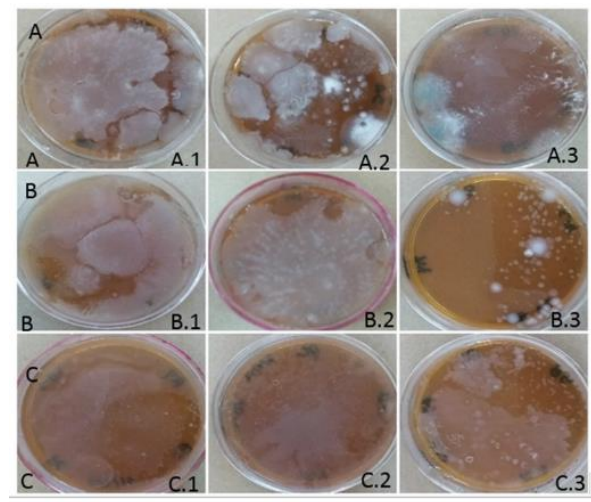

Fig. $\mathbf{N}^{\mathbf{0}}$ 4: Crecimiento en Agar Plate Count y respectivas diluciones en cada suelo; A- Suelo Agrícola (A.1: Dilución 10-1, A.2: Dilución 10-2, A.3: Dilución 10-3); B- Suelo Ganadero (B.1: Dilución 10-1, B.2: Dilución 10-2, B.3: Dilución 10-3); C- Suelo Forestal (C.1: Dilución 10-1, C.2: Dilución 10-2, C.3: Dilución

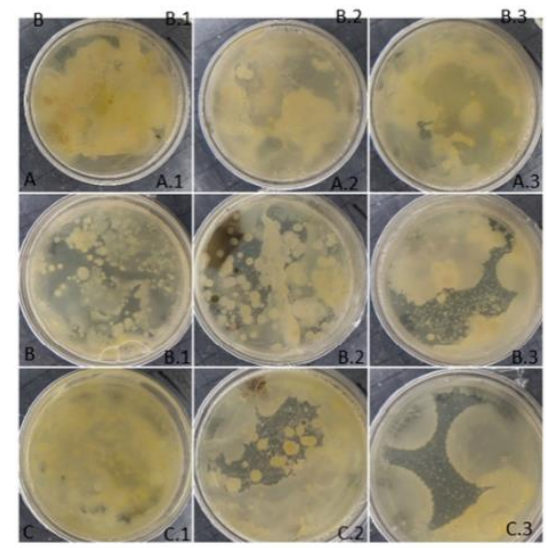


Fig. N $^{\mathbf{5}}$ : Crecimiento en Agar Extracto de Malta y respectivas diluciones en cada suelo; A- Suelo

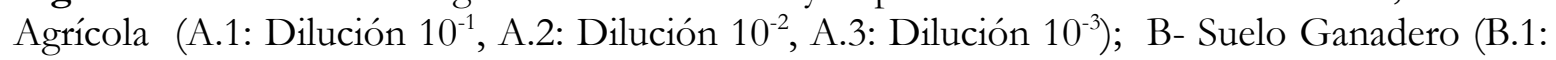
Dilución $10^{-1}$, B.2: Dilución 10-2 B.3: Dilución 10 ${ }^{-3}$ ); C- Suelo Forestal (C.1: Dilución 10-1 , C.2: Dilución $10^{-2}$, C.3: Dilución $10^{-3}$ ).

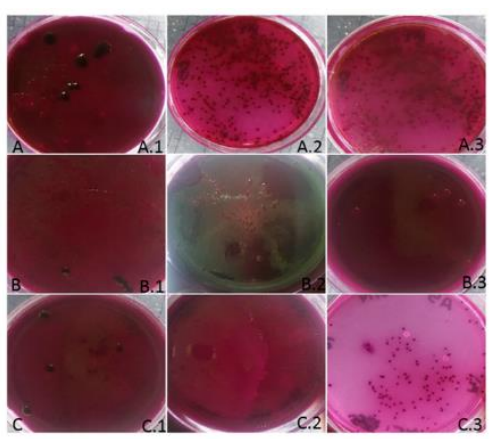

Fig.N\%6: Crecimiento en Agar ENDOLES y respectivas diluciones en cada suelo; A- Suelo

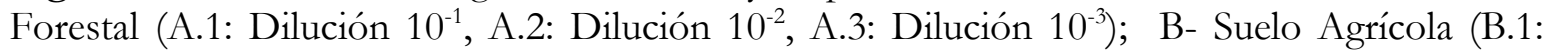
Dilución $10^{-1}$, B.2: Dilución $10^{-2}$, B.3: Dilución $10^{-3}$ ); C- Suelo Ganadero (C.1: Dilución 10 $0^{-1}$, C.2: Dilución $10^{-2}$, C.3: Dilución $10^{-3}$ ).

\section{Medición del $\mathrm{CO}_{2}$}

\section{Respiración del suelo por medida del $\mathrm{CO}_{2}$ atrapado en una disolución de $\mathrm{NaOH}$.}

Cuadro No 2: RESPIRACIÓN DE TRES TIPOS DE SUELO CONSUMIDOS EN HCL EN EL ÁREA DE AZUERO. AÑO: MAYO Y JUNIO DE 2016.

\begin{tabular}{c|c}
\hline Tipo de suelo & ml de HCl consumidos \\
\hline Ganadero & 33,0 \\
Agrícola & 43,3 \\
Bosque forestal & 31,2 \\
Blanco & 51,7 \\
\hline
\end{tabular}

Nota: Estimación del $\mathrm{CO}_{2}$ desprendido durante la incubación del suelo en un sistema cerrado. $\mathrm{El} \mathrm{CO}_{2}$ es atrapado en una disolución de $\mathrm{NaOH}$ que es posteriormente valorado con $\mathrm{HCl}$. 


\section{Respiracion del suelo Vs la titulacion $\mathrm{HCl}$}

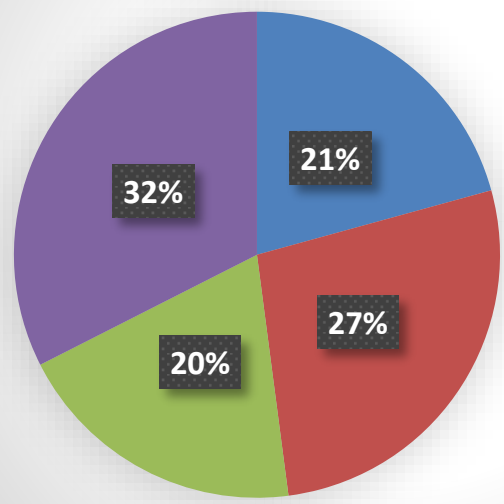

- Ganadero

- Agricola

Bosque forestal

m Blanco

Figura No.7: RESPIRACIÓN DEL $\mathrm{CO}_{2}$ DEL SUELO TITULADO CON HCL CONSUMIDO. EN EL ÁREA DE AZUERO. AÑO: MAYO Y JUNIO DE 2016.

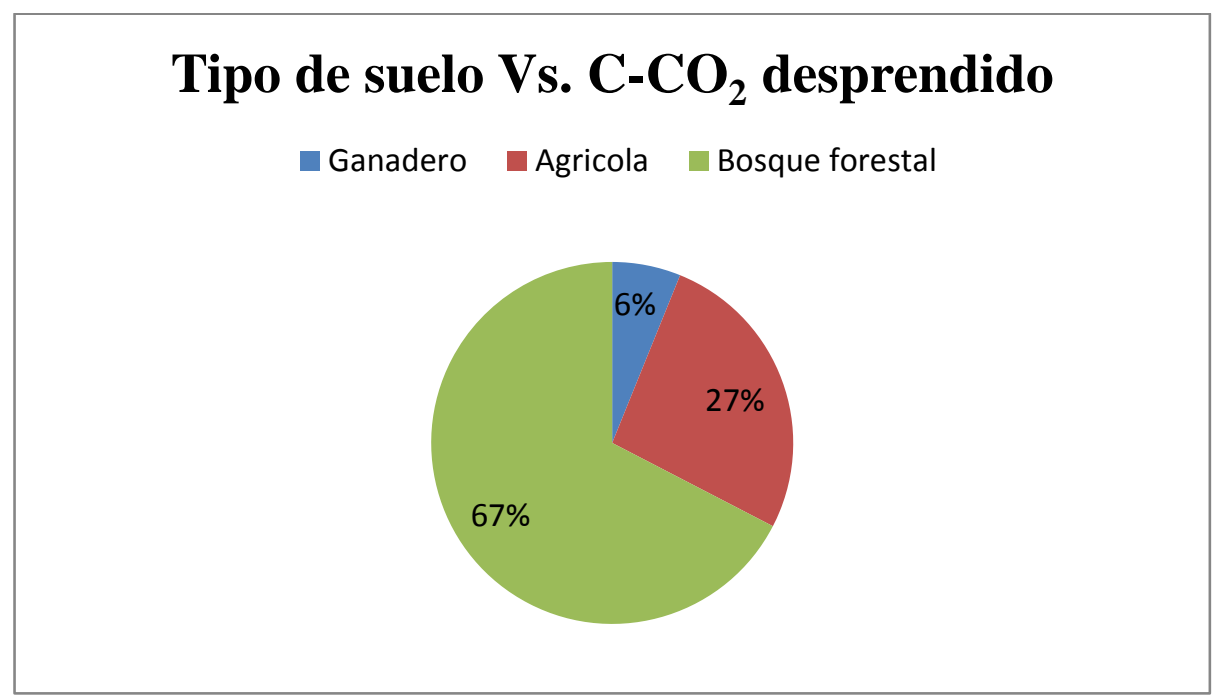

Figura No.8 PORCENTAJE DE C-CO $\mathrm{CO}_{2}$ DESPRENDIDO EN TRES TIPOS DE SUELO.EN EL ÁREA DE AZUERO. AÑO: MAYO Y JUNIO DE 2016.

Los resultados obtenidos podemos observar que el $\mathrm{CO}_{2}$ absorbido y desprendido del suelo el más sobresaliente fue el suelo de bosque forestal con $34,1 \times 10^{-3} \mathrm{mg} \mathrm{C}-\mathrm{CO}_{2} \mathrm{~kg}^{-1}$ suelo seco $\mathrm{día}^{-1}$ ya que tiene una estimación de la biomasa microbiana realmente activa. Mientras que el suelo agrícola tuvo una menor liberación de $\mathrm{CO}_{2} \operatorname{con} 13,4 \times 10^{-3} \mathrm{mg}$ C-CO $\mathrm{Kg}^{-1}$ suelo seco día $^{-1}$, a pesar de que el suelo ganadero también presento un elevado desprendimiento de $\mathrm{CO}_{2}$ aunque es considerado con menos actividad microbiana ya que es pisado muchas veces por el ganado lo cual disminuye su porosidad. 
Determinación de la actividad catalasa del suelo.

Evaluación de la catalasa

Cuadro $\mathbf{N}^{\circ}$ 3: PRUEBA DE CATALASA EN TRES SUELOS TRATADOS EN LA REGIÓN DE AZUERO. AÑO: MAYO Y JUNIO DE 2016.

\begin{tabular}{cccc}
\hline Tipo de suelo & Tratamiento & $\begin{array}{c}\text { Consumo final } \\
(\mathrm{ml})\end{array}$ & $\begin{array}{c}\text { Tiempo consumido } \\
\text { (segundos) }\end{array}$ \\
\hline \multirow{3}{*}{ Ganadero } & Muestra & 5,2 & 6 \\
& Control & 2,2 & 5 \\
& Blanco & 2,7 & 7 \\
\hline \multirow{3}{*}{ Agrícola } & Muestra & 8,2 & 10 \\
& Control & 2,0 & 5 \\
& Blanco & 5,1 & 6 \\
\hline \multirow{3}{*}{ Bosque forestal } & Muestra & 6,1 & 15 \\
& Control & 2,1 & 6 \\
\hline
\end{tabular}

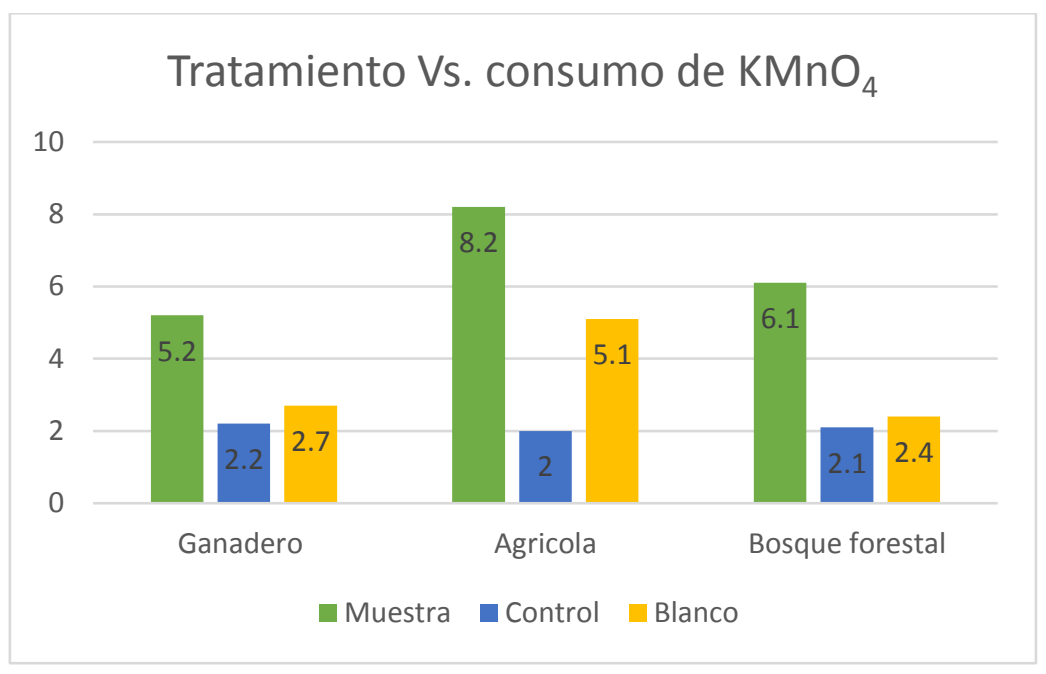

Figura No.9: COMPARACIÓN DE LOS TRATAMIENTOS DE TRES TIPOS DE SUELO CONSUMIDO POR $\mathrm{KMnO}_{4}$.AÑO: MAYO Y JUNIO DE 2016.

Se obtuvo en el suelo ganadero $2,7 \mathrm{ml}$ de $\mathrm{KMnO}_{4}$ gastado en la valoración del blanco sin suelo y con $\mathrm{H}_{2} \mathrm{O}_{2}, 5,2 \mathrm{ml}$ de $\mathrm{KMnO}_{4}$ gastado en la valoración de la muestra con suelo, $\mathrm{H}_{2} \mathrm{O}_{2}$ y $\mathrm{H}_{2} \mathrm{SO}_{4}$, y 2,2 $\mathrm{ml}$ de $\mathrm{KMnO}_{4}$ gastado en la valoración del control y sin $\mathrm{H}_{2} \mathrm{O}_{2}$ correspondiente a cada muestra de suelo. En el suelo agrícola 5,1 $\mathrm{ml}$ de $\mathrm{KMnO}_{4}$ gastado en la valoración del blanco sin suelo y con $\mathrm{H}_{2} \mathrm{O}_{2}, 8,2 \mathrm{ml}$ de $\mathrm{KMnO}_{4}$ gastado en la valoración de la muestra con suelo, $\mathrm{H}_{2} \mathrm{O}_{2}$ y $\mathrm{H}_{2} \mathrm{SO}_{4}$, y 2,0 $\mathrm{ml}$ de $\mathrm{KMnO}_{4}$ gastado en la valoración del control y sin $\mathrm{H}_{2} \mathrm{O}_{2}$ correspondiente a cada muestra de suelo. 
Invest. pens. crit. (ISSN 1812-3864)

Vol. 6, No. 1, enero-abril 2018

pp. 51-64

En el suelo de bosque forestal 2,4 $\mathrm{ml}$ de $\mathrm{KMnO}_{4}$ gastado en la valoración del blanco sin suelo y con $\mathrm{H}_{2} \mathrm{O}_{2}, 6,1 \mathrm{ml}$ de $\mathrm{KMnO}_{4}$ gastado en la valoración de la muestra con suelo, $\mathrm{H}_{2} \mathrm{O}_{2}$ y $\mathrm{H}_{2} \mathrm{SO}_{4}$, y 2,1 $\mathrm{ml}$ de $\mathrm{KMnO}_{4}$ gastado en la valoración del control y sin $\mathrm{H}_{2} \mathrm{O}_{2}$ correspondiente a cada muestra de suelo.

La muestra del suelo agrícola consumió mucho más $\mathrm{KMnO}_{4}$, ya que no se encuentra la enzima catalasa que provoca la descomposición del $\mathrm{H}_{2} \mathrm{O}_{2}$ en $\mathrm{H}_{2} \mathrm{O}$ y $\mathrm{O}_{2}$ y el $\mathrm{H}_{2} \mathrm{O}_{2}$ que permanece inalterado después que tuvo lugar la reacción enzimática. Mientras que el blanco para los tres suelos estudiados debería haber consumido más ya que este no presentaba el suelo.

\section{Conclusión}

Al finalizar esta investigación hemos llegado a la conclusión de que la Hipótesis de investigación fue aceptada ya que se presenta una mayor ocurrencia y diversidad de microorganismos en uno de los tres suelos evaluados.

La aplicación de las técnicas de Microscopia, tinción de Gram y esparcido predispuestas para este proyecto de investigación fueron efectivas a la hora de identificar los microrganismos existentes en los tres tipos de suelo (Agrícola, Ganadero y Forestal).

La cuantificación de los microorganismo encontrados en los tres tipos de suelo (Agrícola, Ganadero y Forestal), en donde el suelo que obtuvo mayor crecimiento fue el agrícola presentando una alta incidencia en la siembra de diluciones en 3 de los 5 medios utilizados Agar ENDOLES, Agar Cetrimide, Agar Plate Count, Agar Extracto de Malta y Agar Tripticasa de Soja.

La comparación de la activación de la catalasa fue mayor en el Suelo Agrícola.

\section{Bibliografía}

ALEF, K. Y NANNIPIERI, P. (1998). Ensyme activities: Catalase activity. En: Alef, K., Nannipieri, P. (editores). Methods in applied soil microbiology and biochemistry, Academic Press. Gran Bretaña

BRITO, F. (2014). Identificación por fenotipo, cuantificación y técnicas moleculares de bacterias a dos profundidades en el cultivo "Hypericum" antes y después del tratamiento de 1-3 Dicloropropeno y Cloropicrina. Tesis de grado presentada como requisito para la obtención del título de Ingeniero en Agroempresa. UNIVERSIDAD SAN FRANCISCO DE QUITO. Quito, mayo 2014.

CASTRO, C. Y FLORES, A. (2014). Determinación de la actividad, densidad microbiana y físicoquímica en tres suelos, bajo diferentes sistemas de manejo agricola, durante los meses de abril y mayo en el Ejido, corregimiento de Santa Ana, Provincia de Los Santos. Tesis de investigación de la escuela de Biología, Centro Regional Universitario de Azuero.

CUEVAS, M., ESPINOSA, G., ILIZALITURRI, C. Y MENDOZA, A. (2012). Métodos ecotoxicológicos para la evaluación de suelos contaminados con hidrocarburos. Instituto Nacional de Ecología (INE). Universidad Veracruzana. p. 38. 
Invest. pens. crit. (ISSN 1812-3864)

Vol. 6, No. 1, enero-abril 2018

pp. $51-64$

GARCÍA, C., GIL, F., HERNÁNDEZ, T., TRASAR, C. (2003). Técnicas de Análisis de Parámetros Bioquímicos en suelos. Medida de Actividades Enzimáticas y Biomasa Microbiana. Editorial Mundi-Prensa. España

IBÁÑEZ, J. (2008). ¿Qué es la Fertilidad del Suelo?: Fertilidad Física, Química y Biológica. Un Universo invisible bajo nuestros pies: Los suelos y la vida. Obtenido el 4 de junio del 2016 en: http://www.madrimasd.org/blogs/universo/2008/01/29/83481.

JASSAL, T., BLACK, T., CAI, K., MORGENSTERN, Z., LI, D., GAUYMONT-GUAY Y NESIC. Z. (2007). Components of ecosystems respiration and an estimate of net primary productivity of an intermediate-aged Douglas-Fir stand. Agric. For. Meteorol. 144: págs. 44-57.

LLOYD, J. Y A. TAYLOR. (1994). On the temperature dependence of soil respiration. Functional Ecology 8: págs. 315-323.

ORGANIZACIÓN DE LAS NACIONES UNIDAS PARA LA ALIMENTACIÓN Y LA AGRICULTURA (UNESCO). (2016). Degradación del Suelo. Ciudad del Saber, Panamá.

RAMOS, J. (2010). TÉCNICAS DE MUESTREO PARA MANEJADORES DE RECURSOS NATURALES. Unidad 6 Los Microorganismos de suelo. Obtenido el 10 de julio del 2016 de http://www2.inecc.gob.mx/publicaciones/libros/429/organismos.pdf.

VÁSQUEZ, J., MACÍAS, F. Y MENJIVAR, J. (2013). Respiración del suelo según su uso y su relación con algunas formas de carbono en el Departamento del Magdalena, Colombia. BIOAGRO versión impresa ISSN 1316-3361. Obtenido el 4 de junio del 2016 en: www.scielo.org.ve/scielo.php?script=sci_arttext\&pid=S1316.

VILLAREAL, J. Y NAME, B. (1996) Monitoreo de cambios en la fertilidad de suelos por medio de análisis de laboratorios. Revista Agronomía Mesoamericana. Págs. 301-309. 